\title{
Phenotypic variation of Pseudomonas putida and $P$. tolaasii affects attachment to Agaricus bisporus mycelium
}

\author{
P. B. RAINEY $\dagger$ \\ Department of Plant and Microbial Sciences, University of Canterbury, Christchurch 1, New Zealand
}

(Received 30 April 1991; revised 29 July 1991; accepted 30 August 1991)

\begin{abstract}
The effect of phenotypic variation on attachment of Pseudomonas tolaasii and $P$. putida to Agaricus bisporus mycelium was investigated. Quantitative studies demonstrated the ability of each isolate to attach rapidly and firmly to $\boldsymbol{A}$. bisporus mycelium and significant differences in attachment of wild-type and phenotypic variant strains were observed. This was most pronounced in $P$. tolaasii, where the percentage attachment of the wild-type form was always greater than that of the phenotypic variant. The medium upon which the bacteria were cultured, prior to conducting an attachment assay, had a significant effect on their ability to attach. Attachment of the wildtype form of $P$. putida was enhanced when the assay was performed in the presence of $\mathrm{CaCl}_{2}$, suggesting the involvement of electrostatic forces. No correlation was observed between bacterial hydrophobicity and ability to attach to $A$. bisporus mycelium. Scanning electron microscopy confirmed the results obtained from the quantitative studies and provided further evidence for marked differences in the ability of the pseudomonads to attach to mycelium. Fibrillar structures and amorphous material were frequently associated with attached cells and appeared to anchor bacteria to each other and to the hyphal surface. A time-course study of attachment using transmission electron microscopy revealed the presence of uneven fibrillar material on the surface of cells. This material stained positive for polysaccharide and may be involved in ensuring rapid, firm attachment of the cells.
\end{abstract}

\section{Introduction}

Adherence of bacteria to surfaces of living organisms can be an important factor in determining the extent to which bacteria influence the growth and development of a 'host'. Colonization of legume roots by Rhizobium spp. is necessary before the bacterium can infect the host cells and incite formation of nitrogen-fixing nodules (Dazzo, 1984). Similarly, colonization of dicot root surfaces is necessary before Agrobacterium tumefaciens can infect its host (Lippincott \& Lippincott, 1969; Matthysse et al., 1978) and colonization of plant root surfaces by rhizobacteria must occur before subsequent effects of the bacteria on promotion, or limitation, of plant growth can occur (Schroth \& Hancock, 1982; De Weger et al., 1987; Bashan et al., 1991).

Growth and development of the cultivated mushroom, Agaricus bisporus, is affected by several pseudomonads (see Grewal \& Rainey, 1991), in particular Pseudomonas putida, which provides $A$. bisporus with the stimulus necessary to 'trigger' basidiome initiation (Eger, 1961; Hayes et al., 1969; Rainey et al., 1990; Rainey, 1991) and

† Present address: NERC Institute of Virology \& Environmental Microbiology, Mansfield Road, Oxford OX1 3SR, UK.

Abbreviations: BATH, bacterial adherence to hydrocarbons; SAT, salt aggregation test; SEM, scanning electron microscopy; TEM, transmission electron microscopy.
P. tolaasii, the causal organism of brown blotch disease (Tolaas, 1915). Bacteria inhabiting the casing layer have been shown to exist in close proximity to $A$. bisporus hyphae (Stanek, 1976) and colonization of mycelium by $P$. tolaasii and $P$. putida has been observed (Preece \& Wong, 1982; Masaphy et al., 1987). Direct contact of bacteria with hyphae is necessary for basidiome initiation to occur (Rainey et al., 1990) and colonization of mycelial surfaces by $P$. tolaasii is thought to be important in relation to the development of brown blotch disease (Preece \& Wong, 1982).

An accompanying paper (Grewal \& Rainey, 1991) describes the chemotactic response of mycelium-derived isolates of $\boldsymbol{P}$. putida and $\boldsymbol{P}$. tolaasii and a phenotypic variant of each species to mycelial exudates of $A$. bisporus. The work described here concerns attachment of the same bacteria (and phenotypic variants) to $A$. bisporus mycelium.

\section{Methods}

Strains and growth conditions. The wild-type strains $P$. putida (PMS1 18S) and $P$. tolaasii (PMS1 17S), and their respective phenotypic variants PMS118R and PMS117R, were as described by Grewal \& Rainey (1991). A. bisporus was grown on compost malt medium (CMM; Rainey, 1989a) in $90 \mathrm{~mm}$ diameter Petri dishes for $10 \mathrm{~d}\left(25^{\circ} \mathrm{C}\right)$ before being used in experiments. Casing soil extract medium $(\mathrm{CX})$ was prepared by mixing $150 \mathrm{~g}$ of $\boldsymbol{A}$. bisporus-colonized casing material 
( 3 parts peat : 1 part lime, $\mathrm{v} / \mathrm{v}$ ) with $200 \mathrm{ml}$ distilled water. The slurry was filtered through Whatman no. 1 filter paper and the $\mathrm{pH}$ adjusted to $\mathrm{pH} 7.3$ with $1 \mathrm{M}-\mathrm{HCl}$. After addition of $1.5 \%(\mathrm{w} / \mathrm{v})$ agar the medium was sterilized by autoclaving $\left(120^{\circ} \mathrm{C}, 15 \mathrm{~min}, 1 \cdot 2 \mathrm{~atm}\right)$.

Determination of bacterial hydrophobicity. Three different methods were used: the salt aggregation test (SAT) (Lindahl et al., 1981), bacterial adherence to hydrocarbons (BATH) (Dillon et al., 1986), and bacterial adherence to polystyrene (Rosenberg, 1981). The SAT test relies on the ability of ammonium sulphate to cause hydrophobic surfaces to aggregate. The concentration of ammonium sulphate required to cause bacterial aggregation is dependent on surface hydrophobicity and decreases as hydrophobicity increases. The lowest concentration causing cell aggregation is the SAT value. The BATH test relies upon partitioning of cells into hydrocarbons. Cells are suspended in buffer and the hydrocarbon added and vortex-mixed. After separation of the phases the optical density of the aqueous phase is measured and the result recorded as the percentage optical density of the aqueous phase relative to the initial optical density of the bacterial suspension. The hydrophobicity of cells grown under nutrient-replete and nutrient-depleted conditions was examined by culturing cells on King's medium B (King et al,, 1954) (KB) and CX medium, respectively.

Quantitative determination of adherence to mycelium. (i) Preparation of bacterial inoculum. Bacteria were cultured on a range of media: KB, minimal medium (M63; Miller, 1972) and M63 medium in which the concentration of carbon and nitrogen were altered: 1/2-M63, glucose $1 \mathrm{~g} \mathrm{l}^{-1},\left(\mathrm{NH}_{4}\right)_{2} \mathrm{SO}_{4} 1 \mathrm{~g} \mathrm{l}^{-1} ; 1 / 10-\mathrm{M} 63$, glucose $0.2 \mathrm{~g} \mathrm{l}^{-1},\left(\mathrm{NH}_{4}\right)_{2} \mathrm{SO}_{4}$ $0 \cdot 2 \mathrm{gl}^{-1} ; \mathrm{M} 63-\mathrm{C}$ (carbon limited), glucose $0.5 \mathrm{~g} \mathrm{l}^{-1},\left(\mathrm{NH}_{4}\right)_{2} \mathrm{SO}_{4}$ $2.0 \mathrm{~g} \mathrm{l}^{-1} ; \mathrm{M} 63-\mathrm{N}$ (nitrogen limited), glucose $2.0 \mathrm{~g} \mathrm{l}^{-1},\left(\mathrm{NH}_{4}\right)_{2} \mathrm{SO}_{4}$ $0.5 \mathrm{~g} \mathrm{l}^{-1}$. Bacteria were also grown on $\mathrm{CX}$ medium. All media were solidified by the addition of $1.5 \%$ agar.

Bacteria were grown overnight $\left(28^{\circ} \mathrm{C}\right)$, harvested with an inoculating loop and suspended in sterile distilled water to give an $\mathrm{OD}_{610}$ of 0.4 $\left(4 \times 10^{8}\right.$ cells $\left.\mathrm{ml}^{-1}\right)$, or if grown on media of reduced nutrient status (which resulted in smaller cells), to give an $\mathrm{OD}_{610}$ of $0.3\left(4 \times 10^{8}\right.$ cells $\mathrm{ml}^{-1}$ ). The suspension was mixed well (but gently) to disrupt bacterial aggregates and motility was checked microscopically before performing each experiment. The effect of $\mathrm{Ca}^{2+}$ on bacterial adhesion was assessed by the addition of $5 \mathrm{mM}-\mathrm{CaCl}_{2}$ to the distilled water.

(ii) Preparation of A. bisporus cultures and attachment assay. Petri dish cultures of $A$. bisporus were flooded with sterile distilled water and left at room temperature for $15 \mathrm{~min}$ to suppress aerial mycelium. Agarmycelial plugs $(10 \mathrm{~mm}$ diam.) were aseptically removed from the margin of the cultures and placed in sterile Petri dishes. After the surface of the agar-mycelial plugs had dried (15 min), a $20 \mu \mathrm{l}$ drop of bacterial suspension was carefully applied and spread using a pipette tip (without touching the mycelium) to cover the entire mycelial surface. Inoculated plugs were incubated for $30 \mathrm{~min}$ at $25^{\circ} \mathrm{C}$ and then any bacteria not firmly attached to the hyphal surfaces were dislodged by vigorously washing each plug in $10 \mathrm{ml}$ phosphate-buffered saline (PBS; $\mathrm{Na}_{2} \mathrm{HPO}_{4} 7 \mathrm{~g} \mathrm{l}^{-1}, \mathrm{KH}_{2} \mathrm{PO}_{4} 3 \mathrm{~g} \mathrm{l}^{-1}, \mathrm{NaCl}_{4} \mathrm{~g} \mathrm{l}^{-1}$, $\mathrm{MgSO}_{4}, 7 \mathrm{H}_{2} \mathrm{O} 0 \cdot 2 \mathrm{~g} \mathrm{l}^{-1}$ ) for $1 \mathrm{~min}$ using a vortex mixer. The number of bacteria not firmly attached to the mycelium and the total number of bacteria applied in the $20 \mu 1$ drop were determined using the drop method of Miles \& Misra (1938). Dilutions were made in PBS and all equipment which made contact with the bacteria was manufactured from polypropylene (initial experiments revealed the inability of these bacteria to attach to polypropylene or to agar plugs).

The number of bacteria attached to hyphal surfaces after $30 \mathrm{~min}$ was calculated by subtracting the number of bacteria initially applied to the mycelial surface of the plug from the number recovered after vortex mixing. The result was expressed as a percentage of the number of bacteria initially placed on the surface of the agar-mycelial plug; each treatment was replicated five times.
Electron microscopy. A. bisporus cultures were flooded with $10 \mathrm{ml}$ bacterial suspension (overnight $\mathrm{KB}$ plate-cultured cells suspended in sterile distilled water to a concentration of $1 \times 10^{8}$ cells $\left.\mathrm{ml}^{-1}\right)$ and reincubated at $25^{\circ} \mathrm{C}$. Plugs of agar and mycelium $(5 \mathrm{~mm}$ diam.) were removed from the colony margin with a sterile cork borer $30 \mathrm{~min}, 3 \mathrm{~h}$, $24 \mathrm{~h}$ and $72 \mathrm{~h}$ after inoculation. Plugs were washed vigorously in sterile distilled water $(2 \times 5 \mathrm{~min})$ before fixing in glutaraldehyde. To investigate the attachment behaviour of bacteria under nutrientdepleted conditions some plugs were removed from the fungal culture $24 \mathrm{~h}$ after inoculation and placed in $5 \mathrm{ml}$ sterile distilled water, where they were left for a further $48 \mathrm{~h}$ before fixation. Plugs incubated in the presence of bacteria for $24 \mathrm{~h}$ or longer were plated onto fresh CMM to check for fungal growth. All treatments were examined by scanning electron microscopy (SEM), but only the $30 \mathrm{~min}, 3 \mathrm{~h}$ and $24 \mathrm{~h}$ treatments were examined by transmission electron microscopy (TEM).

SEM. Mycelial-agar plugs were fixed by immersion in $3 \%(\mathrm{v} / \mathrm{v})$ glutaraldehyde (in $0.075 \mathrm{M}$-potassium phosphate buffer, $\mathrm{pH} 7.2$ ) for $3 \mathrm{~h}$ at $20^{\circ} \mathrm{C}$ and washed in $0.075 \mathrm{M}$-potassium phosphate buffer $(\mathrm{pH} 7 \cdot 2)$. Specimens were dehydrated in a series of ethanol/distilled water mixtures and put through a series of amyl acetate/ethanol mixtures $(4 \mathrm{~h}$ in each solution). They were critical-point dried in a $\mathrm{CO}_{2}$ atmosphere, mounted on stubs and gold-coated for $3 \mathrm{~min}$ in a 'Polaron' diode splutter device (E50000) and examined with a Cambridge stereoscan 250 Mk 2 scanning electron microscope.

TEM. Mycelial-agar plugs were fixed as for SEM and washed in $0.075 \mathrm{M}$-potassium phosphate buffer $(\mathrm{pH} 7 \cdot 2)$, post-fixed in $1 \%(\mathrm{w} / \mathrm{v})$ $\mathrm{OsO}_{4}$ in the same buffer for $3 \mathrm{~h}$, washed again in buffer and dehydrated in an acetone series. Dehydrated material was infiltrated and embedded in Spurr's low-viscosity resin and ultra-thin specimens were cut using an LKB 'Pyramitome' (type 11800). Specimens were routinely stained with uranyl acetate (Watson, 1958). Selected specimens were stained using the Thiéry reaction (TCH staining; Thiéry, 1967), with appropriate controls, to detect periodate-sensitive polysaccharide material. Specimens were examined in a JEM-1200EX electron microscope at an accelerating voltage of $80 \mathrm{kV}$.

Statistical analysis. Statistical analysis was performed using standard ANOVA techniques. Comparisons between means were made using Fisher's protected least significant difference (LSD) test.

\section{Results}

\section{Hydrophobicity of $P$. putida and P. tolaasii}

SAT assay. The results from the SAT assay are shown in Table 1 . Both variants of $P$. tolaasii appeared moderately hydrophobic and the hydrophobicity of the wild-type

Table 1. Hydrophobicity of wild-type and phenotypic variants of $P$. putida and $P$. tolaasii after growth on $K B$ and $C X$ as determined by the SAT assay

Values are the lowest $\left(\mathrm{NH}_{4}\right)_{2} \mathrm{SO}_{4}$ molarity giving bacterial aggregation.

\begin{tabular}{lrr}
\hline \hline & \multicolumn{2}{c}{ Medium } \\
\cline { 2 - 3 } Bacterial isolate & KB & CX \\
\hline P. putida PMS118S & $>4 \cdot 0$ & $4 \cdot 0$ \\
$P$. putida PMS118R & $>4 \cdot 0$ & $4 \cdot 0$ \\
$P$. tolaasii PMS117S & $2 \cdot 0$ & $1 \cdot 6$ \\
$P$. tolaasii PMS117R & $2 \cdot 0$ & $2 \cdot 0$ \\
\hline \hline
\end{tabular}




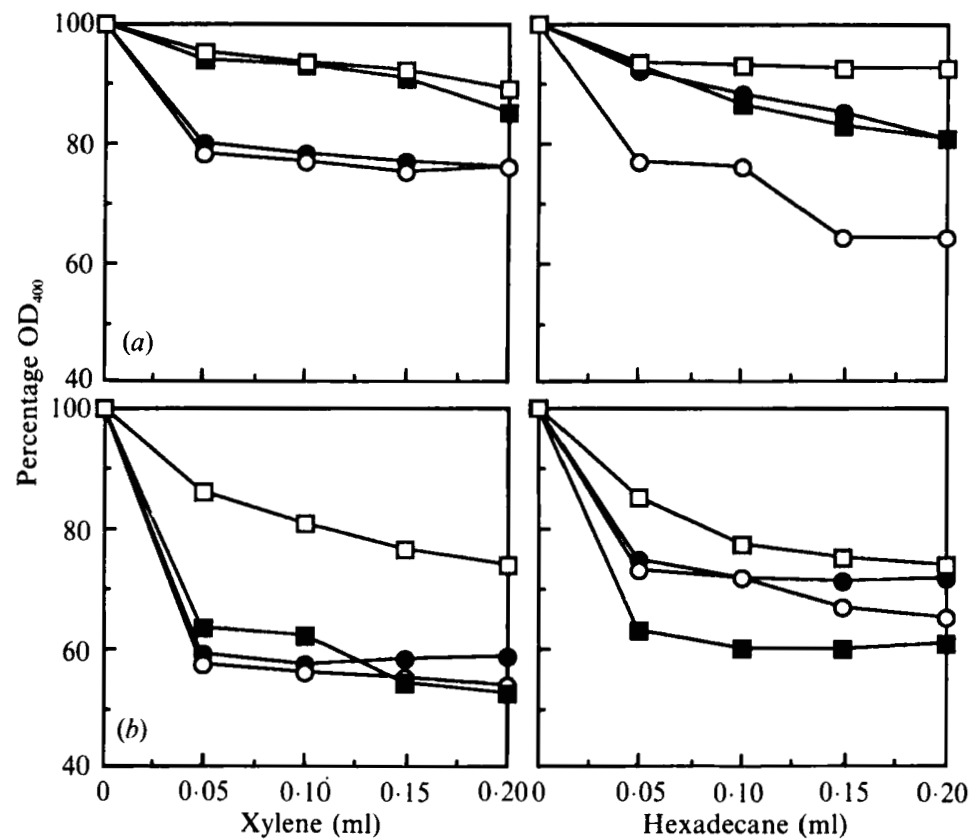

Fig. 1. Adherence of wild-type and phenotypic variant forms of $P$. putida (PMS118S, ; PMS118R, $O$ ) and $P$. tolaasii (PMSI17S, $\square$; PMSI17R, $\square$ ) to varying volumes of $p$-xylene and $n$-hexadecane after growth on (a) KB medium and (b) CX medium in the BATH assay. Data are means of duplicates. form increased after growth on CX. An end-point was not produced for KB-cultured $P$. putida, but aggregation did occur in $4.0 \mathrm{M}$-ammonium sulphate after the cells were grown on $\mathrm{CX}$, indicating that both $P$. putida forms were relatively hydrophilic.

$B A T H$ assay. Fig. 1 shows adherence of wild-type and phenotypic variants of $\boldsymbol{P}$. putida and $\boldsymbol{P}$. tolaasii to xylene and hexadecane. Adherence of the isolates to xylene after growth on KB suggested that the phenotypic variants of both $P$. putida and $P$. tolaasii were weakly hydrophobic. Hexadecane gave similar results. The hydrophobicity of all isolates increased after growth on CX.

Bacterial adherence to polystyrene assay. All isolates showed a limited ability to adhere to polystyrene and scored a weak positive result for this test, indicating that the cells were weakly hydrophobic.

\section{Quantitative studies}

Attachment of the wild-type and the phenotypic variant of $P$. putida to A. bisporus mycelium is shown in Fig. 2(a). A two-way ANOVA revealed no significant difference between the ability of the wild-type and phenotypic variant to adhere to mycelium, but the medium on which the cells were grown, prior to performing the attachment assay, had a significant effect on attachment $(P<0.001)$. The interaction between the different variants and media on which they were grown was also significant $(P<0.001)$.

Growth of both $P$. putida strains on CX caused the percentage attachment to increase and the percentage attachment of the phenotypic variant (PMS118R) was significantly greater than on any other medium $(P<0.001)$. When the attachment assay was conducted in the presence of $5 \mathrm{mM}-\mathrm{CaCl}_{2}$ there was a significant increase in adherence of the wild-type form (PMS118S) to mycelium $(P<0.001)$ when compared to adherence of this form after growth on $\mathrm{KB}$ or $\mathrm{M63}$. Addition of $\mathrm{CaCl}_{2}$ did not increase the percentage attachment of the phenotypic variant when compared to the percentage attachment of this form after growth on either KB or M63.

Adherence of the wild-type and the phenotypic variant of $P$. tolaasii to $A$. bisporus mycelium is illustrated in Fig. 2(b). A significant difference was found between the ability of the two forms to adhere to mycelium $(P<0.001)$ and the effect of different media on adherence was also significant. The interaction between these two factors was significant $(P<0.001)$.

Wild-type $P$. tolaasii (PMS117S) consistently attached to the mycelium in greater numbers than the phenotypic variant and attachment of the wild-type organism was greatest when cultured on nitrogen-limited M63 and CX. Compared with these two media, the percentage attachment of the wild-type form decreased significantly when the attachment assay was performed in the presence of $\mathrm{CaCl}_{2}$, but the percentage of bacteria which attached to the mycelium under these conditions was comparable to that observed after culture on KB or M63. On 1/10-M63, attachment of the wild-type form was significantly reduced $(P<0.05)$ compared to the attachment of this form after growth on KB and M63. The percentage attachment of the phenotypic variant (PMS117R) was 

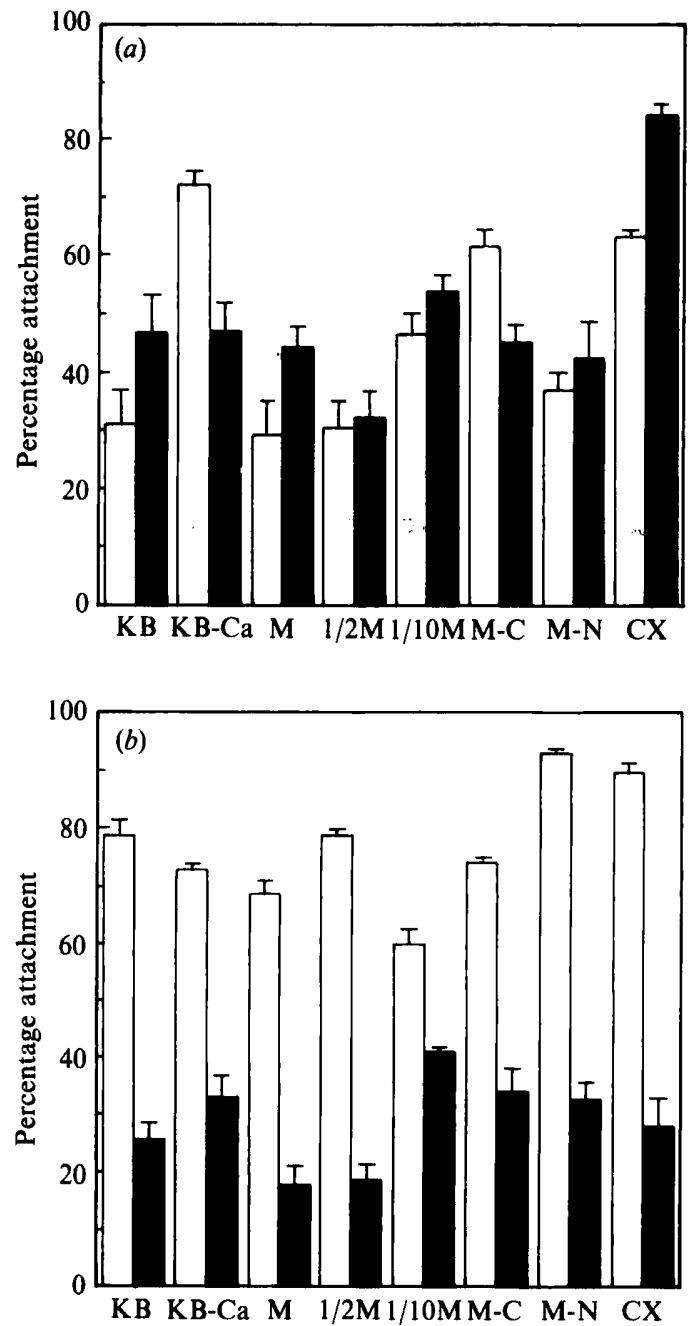

Fig. 2. Effect of culture conditions on attachment of wild-type and phenotypic variant forms of (a) P. putida (wild-type PMS118S, $\square$; phenotypic variant PMS118R, $\square$ ) and $(b) P$. tolaasii (wild-type PMS117S, $\square$; phenotypic variant PMS117R, $\square$ ) to A. bisporus mycelium. KB, KB medium; KB-Ca, KB-cultured cells, but assay conducted in the presence of $5 \mathrm{mM}-\mathrm{CaCl}_{2} ; \mathrm{M}$, minimal M63 medium; 1/2M, $0.5 \times \mathrm{M} 63 ; 1 / 10 \mathrm{M}, 0.1 \times \mathrm{M} 63 ; \mathrm{M}-\mathrm{C}$, carbon limited M63; M-N, nitrogen limited M63; CX, casing extract medium (see text for full description). Data are means and SE of five replicates.

greatest after culture on $1 / 10-\mathrm{M} 63$. Conducting the attachment assay in the presence of $5 \mathrm{mM}-\mathrm{CaCl}_{2}$, or growing the phenotypic variant on $\mathrm{CX}$, had little effect on its ability to attach to mycelium.

\section{Microscopic studies of adherence}

SEM. Figs 3(a)- $(f)$ show bacteria attached to $A$. bisporus mycelium after $30 \mathrm{~min}$. Both the wild-type and phenotypic variant of $P$. putida attached to the mycelium in large numbers and in most instances the bacteria lay flat against the hyphae (Fig. $3 a, b$ ), although some were seen attached by one end only. Wild-type $P$. tolaasii cells also attached to the mycelium in large numbers and were often orientated perpendicular to hyphal surfaces (Fig. $3 c$ ). Few cells of the phenotypic variant of $P$. tolaasii were seen attached to the mycelial surfaces (Fig. $3 d$ ).

Fibrillar rods were frequently associated with the attached bacteria (Fig. $3 e, f$ ) and appeared to join the bacteria both to the mycelial surfaces and to each other. These rod-like structures did not resemble flagella, or fimbriae.

Differences in the patterns of attachment, especially of the wild-type and phenotypic variants of $P$. putida, became evident after the bacteria were left for longer than $30 \mathrm{~min}$ in the presence of the mycelium. Examination of the mycelial plugs after $3 \mathrm{~h}$ and $24 \mathrm{~h}$ revealed little change, although the number of phenotypic variant $P$. putida cells attached appeared to decline. After $72 \mathrm{~h}$ in the presence of the mycelium (the last $48 \mathrm{~h}$ in distilled water), very few wild-type $P$. putida cells were seen attached to the mycelium and those present were confined to small micro-colonies (Fig. $4 a$ ). In contrast, a large number of $P$. putida variant cells were attached and were evenly distributed over the mycelial surface. These cells were orientated perpendicular to the mycelial surface (Fig. $4 b$ ). The number of cells of the wild-type form of $P$. tolaasii which remained in contact with the mycelium after this treatment appeared to decline, but not to the extent observed in $P$. putida, and distinct micro-colonies were not observed (Fig. 4e). Few cells of the phenotypic variant of this species were seen in contact with the mycelium (Fig. $4 f$ ). Similar results were observed when this material was examined by light microscopy, without prior fixation, or staining (results not shown).

Examination of the mycelial plugs $72 \mathrm{~h}$ after inoculation of CMM cultures with bacteria revealed a large number of wild-type $P$. putida and $P$. tolaasii cells attached to the mycelium and large amounts of amorphous material associated with the cells, possibly polysaccharide slime (Fig. $4 \mathrm{c}$ ). The number of phenotypic variant $P$. putida cells which remained attached after $72 \mathrm{~h}$ under these nutrient-replete conditions declined (Fig. $4 d$ ) and few cells of the variant form of $P$. tolaasii were observed in contact with the mycelium.

Mycelial plugs removed from the 'broth' after $3 \mathrm{~d}$ grew when plated on CMM.

TEM. Figs $5(a)-(d)$ show attachment of the wild-type form of $P$. putida to $A$. bisporus mycelium. Initial attachment appeared to occur after contact was made between the uneven surface of the bacterium and the hyphae. Accumulation of amorphous material between the hyphal surface and attached bacteria was observed 

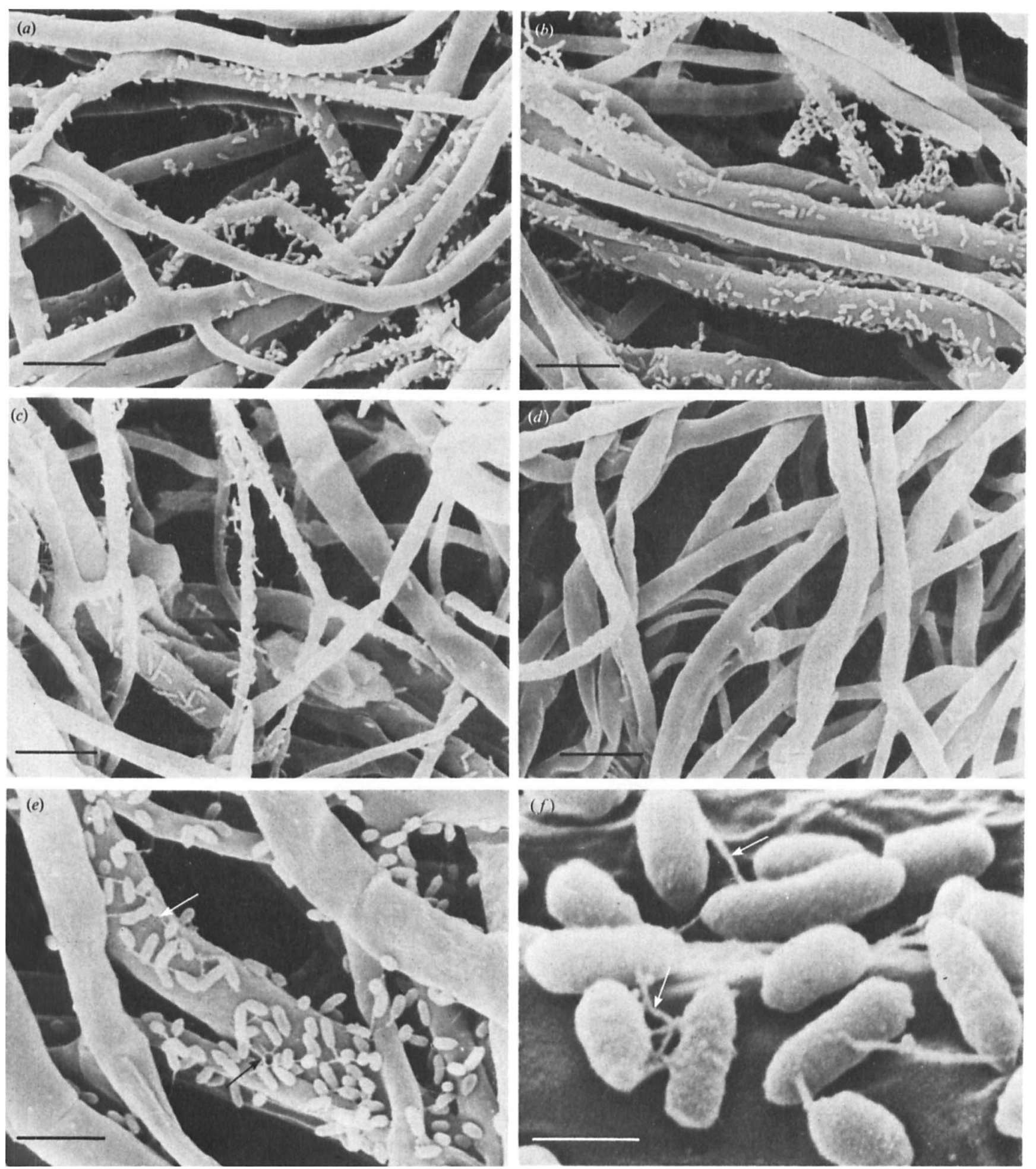

Fig. 3. Scanning electron micrographs of $A$. bisporus mycelium colonized by $P$. putida and $P$. tolaasii 30 min after application of the bacteria. (a-e) Attachment of (a) wild-type $P$. putida (PMS1 18S), (b) phenotypic variant $P$. putida (PMS1 18R), (c) wild-type $P$. tolaasii (PMSII7S), $(d)$ phenotypic variant $P$. tolaasii (PMS1 17R), (e) wild-type $P$. putida (PMS1 18S) showing fibrillar material. $(f)$ High-power micrograph showing detail of fibrillar material associated with attached wild-type $P$. putida (PMS118S) cells. Arrows indicate fibrillar material connecting bacteria to each other and to the mycelial surface. Bars represent $10 \mu \mathrm{m}(a-d), 5 \mu \mathrm{m}(e)$ and $1 \mu \mathrm{m}(f)$. 

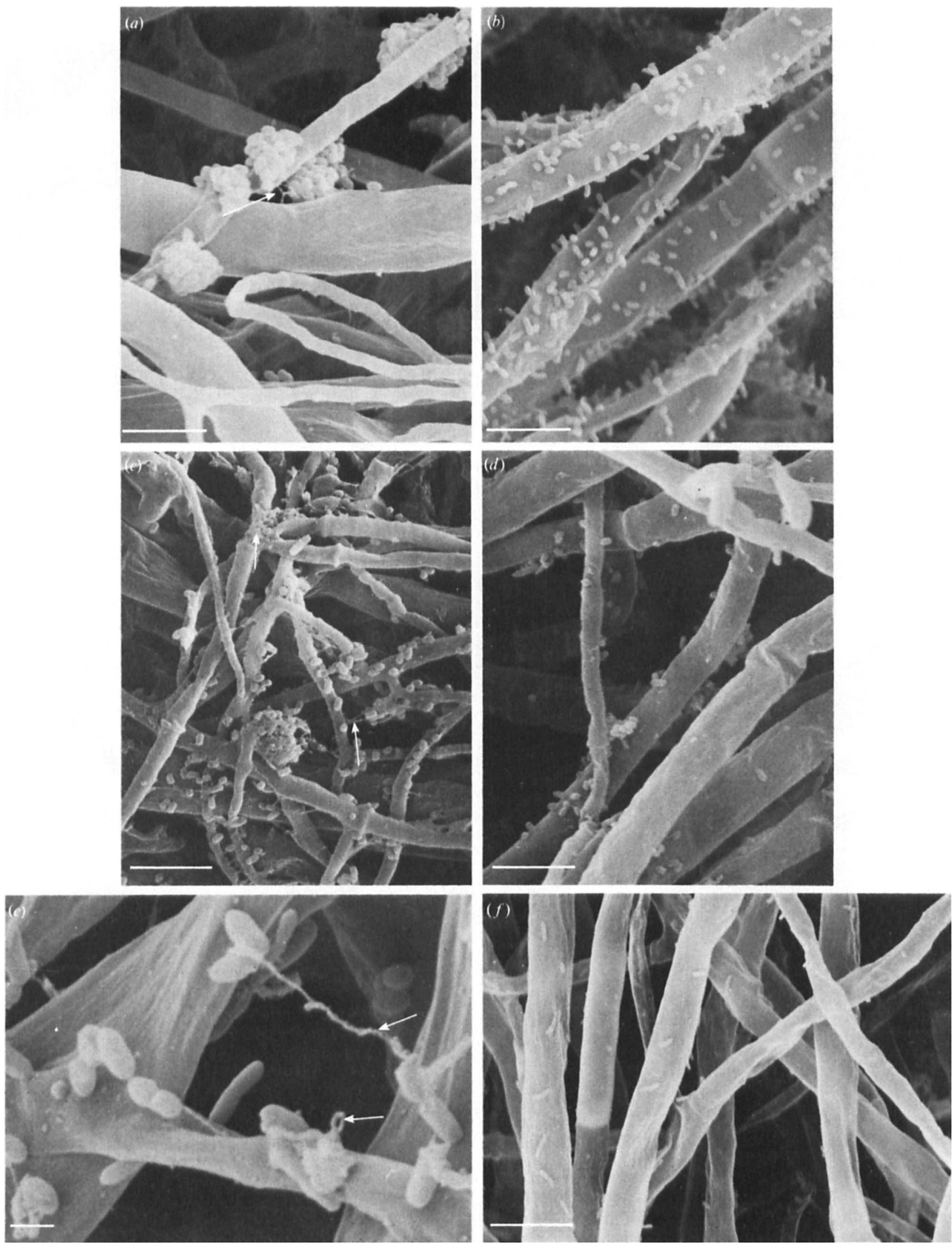

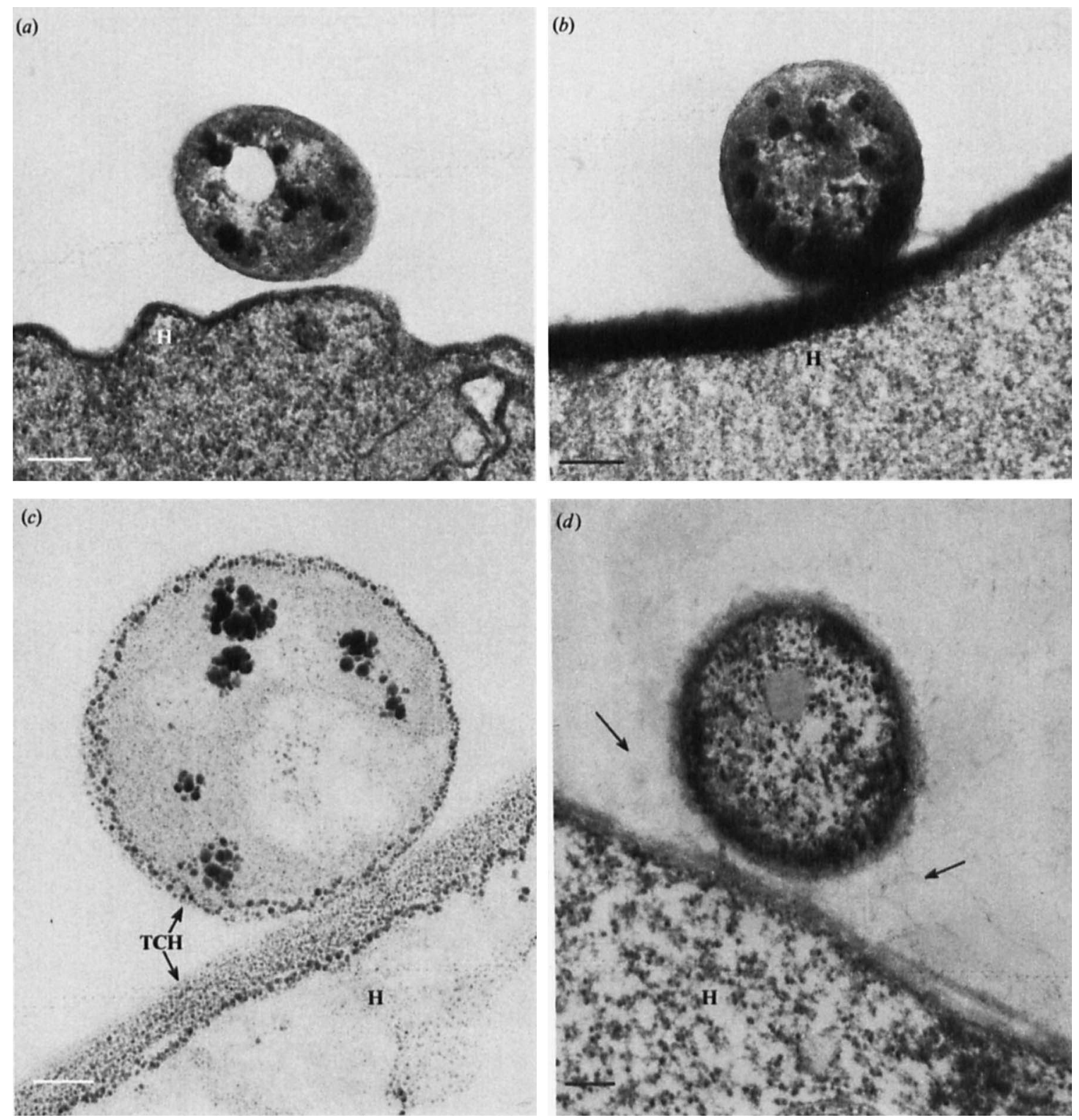

Fig. 5. Transmission electron micrographs of wild-type $P$. putida (PMS118S) cells attached to $A$. bisporus hyphae. (a) After 30 min, (b) after $3 \mathrm{~h},(c)$ after $3 \mathrm{~h}$, showing TCH-positive staining material enveloping the bacterium and hyphae, and (d) after $24 \mathrm{~h}$, showing buildup of amorphous material between the bacterium and hyphal surface (arrows). H, hypha; TCH, TCH-positive staining material. Bars represent $200 \mathrm{~nm}(a$ and $b)$ and $100 \mathrm{~nm}(c$ and $d)$.

after $3 \mathrm{~h}$, but was most pronounced after $24 \mathrm{~h}$. The amorphous material appeared to 'cement' bacteria firmly to the hyphal surface. TCH staining revealed this material to be polysaccharide and it formed a continuum between the bacterium and the surface of the fungus (Fig. $5 c, d$ ). TCH-staining material was observed on the

Fig. 4. Scanning electron micrographs of $A$. bisporus mycelium colonized by $P$. putida and $P$. tolaasii. (a) Microcolonies of wild-type $P$. putida (PMS118S) attached to $A$. bisporus mycelium after $24 \mathrm{~h}$ in CMM and $48 \mathrm{~h}$ in distilled water. (b) Phenotypic variant $P$. putida (PMS118R) attached to $A$. bisporus mycelium after $24 \mathrm{~h}$ in CMM and $48 \mathrm{~h}$ in distilled water. (c) Wild-type $P$. putida (PMS118S) attached to $A$. bisporus mycelium after $72 \mathrm{~h}$ in CMM. (d) Phenotypic variant $P$. putida (PMS118R) attached to $A$. bisporus mycelium after $72 \mathrm{~h}$ in CMM. (e) Wild-type $P$. tolaasii (PMS117S) attached to $A$. bisporus mycelium after $24 \mathrm{~h}$ in CMM and $48 \mathrm{~h}$ in distilled water. $(f)$ Phenotypic variant $P$. tolaasii (PMS117R) attached to $A$. bisporus mycelium after $24 \mathrm{~h}$ in CMM and $48 \mathrm{~h}$ in distilled water. Arrows indicate fibrillar and amorphous material connecting bacteria to each other and to the mycelial surface. Bars represent $5 \mu \mathrm{m}(a-d$ and $f)$, and $1 \mu \mathrm{m}(e)$. 

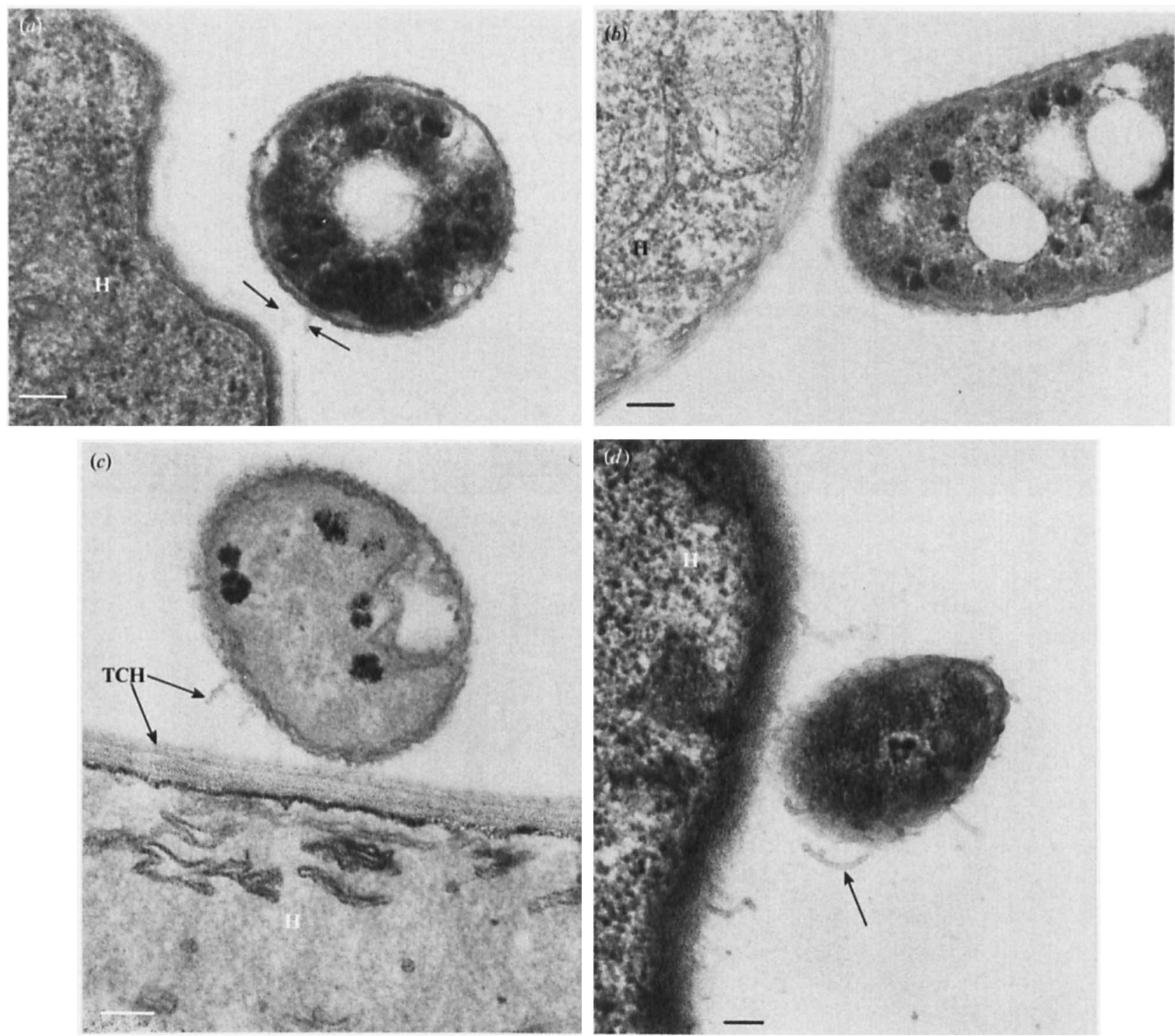

(e)

(f)
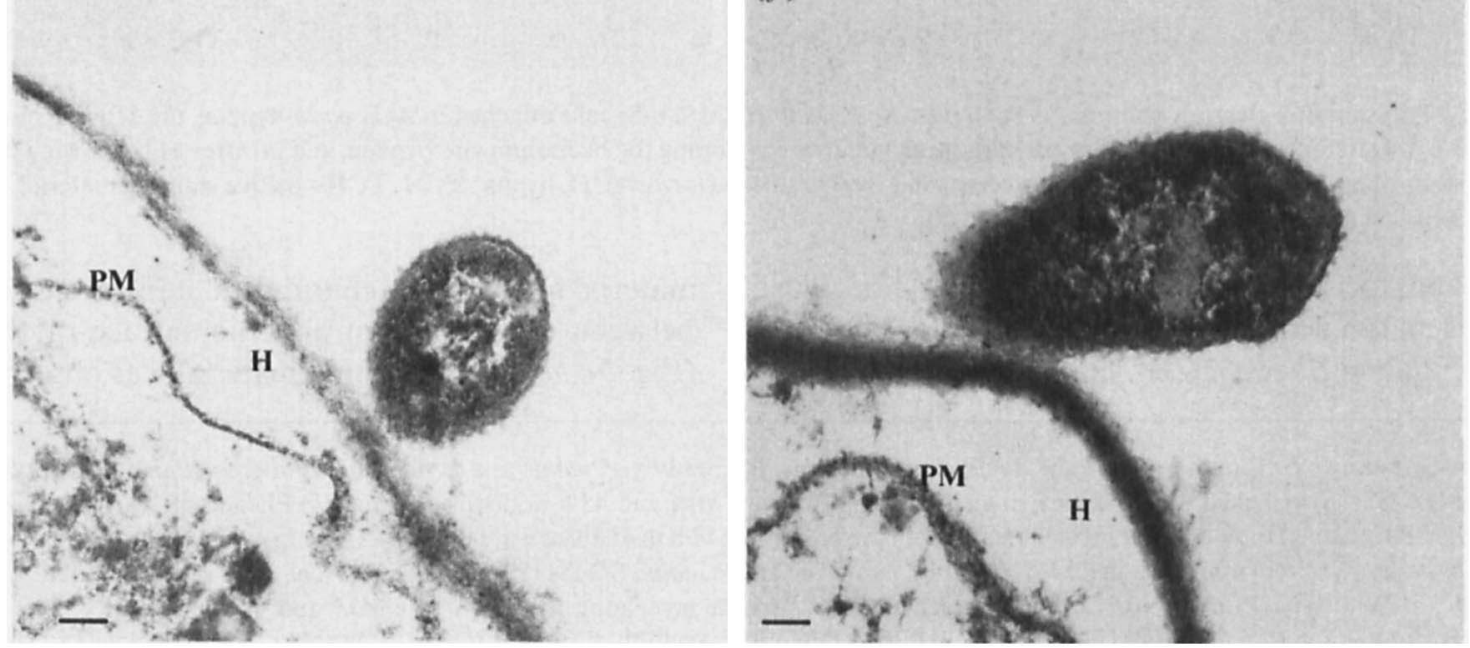
surface of bacteria and hyphae prior to inoculation of mycelium with bacteria.

Attachment of the phenotypic variant of $P$. putida is shown in Figs $6(a)-(d)$. The surface of this variant was particularly uneven and fibrillar rods, frequently longer than $100 \mathrm{~nm}$, were observed protruding from the surface. $\mathrm{TCH}$ staining indicated that they were polysaccharide in nature (Fig. $6 c$ ). Fibrillar rods were also evident in the $24 \mathrm{~h}$ material and were more numerous and longer (up to $300 \mathrm{~nm}$ ) than those seen after $3 \mathrm{~h}$ (Fig. $6 d$ ).

Short fibrillar rods were also seen protruding from the surface of wild-type $P$. tolaasii cells (Fig. $6 e, f$ ). The phenotypic variant of $P$. tolaasii was not seen under TEM, despite examination of five grids (approximately 10 sections per grid). This was indicative of the low number of cells which attached to the mycelium.

\section{Discussion}

A variety of complex interactions, including hydrophobic (Rosenberg \& Kjelleberg, 1986) and electrostatic forces (Marshall et al., 1971), are thought to account for attachment of bacteria to living surfaces. Several studies (Fletcher \& Loeb, 1979; Lindahl et al., 1981; Loosdrecht et al., 1987) have shown a positive correlation between bacterial hydrophobicity and the ability of cells to colonize living surfaces. $P$. putida and $P$. tolaasii were able to adhere rapidly and firmly (that is, cells were not removed by washing) to the surface of $A$. bisporus mycelium, despite being relatively hydrophilic. This suggests that hydrophobic interactions may not play a significant role in the attachment process. Enhanced attachment of wild-type $P$. putida (PMS118S) in the presence of $\mathrm{CaCl}_{2}$ indicates involvement of electrostatic forces (Marshall et al., 1971; James et al., 1985). Similar cation effects have been reported for adherence of $P$. tolaasii to barley roots (Nissen, 1973), adherence of $P$. aeruginosa to steel (Stanley, 1983), adherence of a marine pseudomonad to glass (Marshall et al., 1971) and adherence of $P$. fluorescens to radish roots (James et al., 1985). The presence of uneven polysaccharide polymers and fibrillar appendages on the surface of $P$. putida and $P$. tolaasii may be important in attachment, enabling these bacteria to overcome the repulsion energy barrier which results when two negatively charged surfaces are brought close together (Rutter \& Vincent, 1980;
Fletcher, 1980) and achieve rapid, firm attachment to the hyphal surface. The build-up of polysaccharide material between the bacteria and hyphae may help to anchor the cells firmly to each other and to the hyphal surface (Marshall et al., 1971; Fletcher, 1980).

Adhesive properties of bacteria are affected by a range of physiological and environmental conditions (Fletcher, 1980). The quantitative studies demonstrate the importance of conducting attachment assays under conditions which approximate the situation in vivo. Preece \& Wong (1982) examined attachment of a range of bacteria to discs of mushroom cap mycelium after growth on nutrient agar and reported a percentage attachment value of $31 \%$ for $P$. putida and $74 \%$ for $P$. tolaasii. They concluded that the attachment process, in quantitative terms, differed markedly between pathogens and nonpathogens. The results from this study show that after growth on media more representative of the nutrient status of the casing layer, the difference between the percentage attachment of $P$. putida and $P$. tolaasii was not marked.

Results from the SEM study confirmed the findings of the quantitative attachment work. Fibrillar rods associated with the attached cells were also reported by Preece \& Wong (1982), who found them joining $P$. tolaasii cells to each other, and to $A$. bisporus hyphae. Similar structures have been found anchoring Agrobacterium to plant cells (Matthysse, 1983; Graves et al., 1988) and lactobacilli to chicken crop epithelium (Fuller \& Brooker, 1980). Brooker \& Fuller (1975) were able to show that the fibrillar material had the staining characteristics typical of carbohydrate material. Fibrillar-like material has also been observed linking Rhizobium cells to Phytophthora megasperma hyphae (Tu, 1979) and to P. cinnamomi (Malajczuk et al., 1984) and anchoring Azospirillum brasilense $\mathrm{Cd}$ to plant roots (Bashan et al., 1991).

Phenotypic variants of $P$. putida and of $P$. tolaasii were shown to migrate more rapidly toward $A$. bisporus mycelial exudate than the wild-type forms (Grewal \& Rainey, 1991) and in the light of earlier studies (Rainey, $1989 b$ ) it has been suggested that the phenotypic variant, in each instance, is more suited to survival under nutrient-depleted conditions. This study has revealed further differences in the behaviour of phenotypic variants and wild-type cells. The differences were most

Fig. 6. Transmission electron micrographs of $P$. putida and $P$. tolaasii cells attached to $A$. bisporus hyphae. (a) Phenotypic variant $P$. putida (PMS1 18R) attached to A. bisporus hyphae after $30 \mathrm{~min}$. Note contact between fibrillar apendages and surface of hypha (arrows). (b) Phenotypic variant $P$. putida (PMS118R) attached to $A$. bisporus hypha after 3 h. (c) Same as (b), but TCH stained. (d) Phenotypic variant $P$. putida (PMS118R) attached to $A$. bisporus hypha after $24 \mathrm{~h}$. Note long fibrillar appendages (arrow). (e) Wild-type $P$. tolaasii (PMS117S) attached to $A$. bisporus hypha after $3 \mathrm{~h}$ and $(f)$ after $24 \mathrm{~h}$. Note effects of tolaasin (toxin) activity: plasma membrane pulled away from hyphal wall and loss of cell contents. H, hypha; PM, plasma membrane; TCH, TCH-positive staining material. Bars represent $100 \mathrm{~nm}(a-f)$. 
pronounced in $P$. tolaasii, where the wild-type form consistently attached to mycelium in greater numbers than the phenotypic variant. In $P$. putida quantitative studies revealed little difference between the ability of the two forms to attach, but a striking difference in behaviour became evident after $P$. putida was incubated with mycelium for a prolonged period under nutrientdepleted conditions. Bashan et al. (1991) have also described differences in attachment behaviour of two forms of Azospirillum brasilense $\mathrm{Cd}$ and suggested that cyst forms are a response to water-stressed conditions.

The different attachment behaviour shown by the phenotypic variants highlights the pleiotropic nature of phenotypic variation. While the ecological significance of this behaviour remains to be fully elucidated, the ability of these pseudomonads to produce cell-types which differ in their ability to attach to surfaces is likely to extend the range of habitats in which they can persist and confer a survival advantage upon the species.

I am grateful to Professor T. R. G. Gray and Dr A. L. J. Cole for useful discussion and constructive comments on drafts of the manuscript and to $\mathrm{Dr} \mathrm{N}$. Ricker, Mr M. Ingerfield and $\mathrm{Mr} \mathbf{R}$. N. Andrews for assistance with electron microscopy.

\section{References}

Bashan, Y., LeVanony, H. \& Whitmoyer, R. E. (1991). Root surface colonization of non-cereal crop plants by pleomorphic Azospirillum brasilense Cd. Journal of General Microbiology 137, 187-196.

BroOKER, B. E. \& Fuller, R. (1975). Adhesion of lactobacilli to the chicken crop epithelium. Journal of Ultrastructural Research 52, 2131 .

DAzzo, F. B. (1984). Bacterial adhesion to root surfaces. In Microbial Adhesion and Aggregation, pp. 85-93. Edited by K. C. Marshall. Berlin: Springer Verlag.

De Weger, L. A., Van der Vlugt, C. I. M., Wijfjes, A. H. M., BAKKer, P. A. H. M., SChIPPERS, B. \& LUGTENBerG, B. (1987). Flagella of a plant-growth-stimulating Pseudomonas fluorescens strain are required for colonization of potato roots. Journal of Bacteriology 169, 2769-2773.

Dillon, J. K., Fuerst, J. A., Hayward, A. C. \& Davis, G. H. G. (1986). A comparison of five methods for assaying bacterial hydrophobicity. Journal of Microbiological Methods 6, 13-19.

EGER, G. (1961). Untersuchungen über die Function der Deckschicht bie der Fruchtkorperbildung des Kulterchampignons, Psalliota bispora Lge. Archiv für Mikrobiologie 39, 313-334.

FLETCHER, M. (1980). The question of passive versus active attachment mechanisms in non-specific bacterial adhesion. In Microbial Adhesion to Surfaces, pp. 197-210. Edited by R. C. W. Berkeley, J. M. Lynch, J. Melling, P. R. Rutter \& B. Vincent. Chichester: Ellis Horwood.

FletCHER, M. \& LOEB, G. I. (1979). Influence of substratum characteristics on the attachment of a marine pseudomonad to solid surfaces. Applied and Environmental Microbiology 37, 67-72.

FULLER, R. \& BROOKER, B. E. (1980). The attachment of bacteria to the squamous epithelial cells and its importance in the microecology of the intestine. In Microbial Adhesion to Surfaces, pp. 495-507. Edited by R. C. W. Berkeley, J. M. Lynch, J. Melling, P. R. Rutter \& B. Vincent. Chichester: Ellis Horwood.

Graves, A. E., Goldman, S. L., Banks, S. W. \& Graves, A. C. F. (1988). Scanning electron microscope studies of Agrobacterium tumefaciens attachment to Zea mays, Gladiolus sp., and Triticum aestivum. Journal of Bacteriology 170, 2395-2400.
Grewal, S. I. S. \& Rainey, P. B. (1991). Phenotypic variation of Pseudomonas putida and $P$. tolaasii affects the chemotactic response to Agaricus bisporus mycelium. Journal of General Microbiology 137, 2761-2768.

Hayes, W. A., Randle, P. E. \& Last, F. T. (1969). The nature of the microbial stimulus affecting sporophore formation in Agaricus bisporus (Lange) Sing. Annals of Applied Biology 64, 177-187.

James, D. W., SusLow, T. V. \& SteinNBaCK, K. E. (1985). Relationship between rapid, firm adhesion and long-term colonization of roots by bacteria. Applied and Environmental Microbiology 50, 392-397.

KING, E. O., WARD, M. K. \& RANEY, D. C. (1954). Two simple media for the demonstration of pyocyanin and fluorescin. Journal of Laboratory and Clinical Medicine 44, 301-307.

Lindahl, M., Faris, A., Wadstrom, T. \& HJERTEN, S. (1981). A new test based on 'salting out' to measure relative surface hydrophobicity of bacterial cells. Biochimica et Biophysica Acta 677, 471-476.

LIPPINCOTT, B. B. \& LiPPENCOTT, J. A. (1969). Bacterial attachment to a specific wound site as an essential stage in tumour initiation by Agrobacterium tumefaciens. Journal of Bacteriology 97, 620-628.

Loosdrecht, M. C. M., Lyklema, J., Norde, W., SChraA, G. \& ZEHNDER, A. J. B. (1987). The role of bacterial cell wall hydrophobicity in adhesion. Applied and Environmental Microbiology 53, 1893-1897.

MalajCzuk, N., Pearce, M. \& Litchfield, R. T. (1984). Interactions between Phytophthora cinnamomi and Rhizobium isolates. Transactions of the British Mycological Society 82, 491-500.

Marshall, K. C., Stout, R. \& Mitchell, R. (1971). Mechanism of the initial events in the sorption of marine bacteria to surfaces. Journal of General Microbiology 68, 337-348.

Masaphy, S., LeVanon, D., TChelet, R. \& Henis, Y. (1987). Scanning electron microscope studies of interactions between Agaricus bisporus (Lang) Sing hyphae and bacteria in casing soil. Applied and Environmental Microbiology 53, 1132-1137.

Matthysse, A. G. (1983). Role of cellulose fibrils in Agrobacterium tumefaciens infections. Journal of Bacteriology 154, 906-915.

Matthysse, A. G., Wyman, P. M. \& Holmes, K. V. (1978). Plasmiddependent attachment of Agrobacterium tumefaciens to plant tissue culture cells. Infection and Immunity 22, 516-522.

Miles, A. A. \& MiSRA, S. S. (1938). The estimation of the bactericidal power of the blood. Journal of Hygiene 38, 732-749.

MILLER, J. H. (1972). Experiments in Molecular Genetics. Cold Spring Harbor, NY: Cold Spring Harbor Laboratory.

Nissen, P. (1973). Bacteria-mediated uptake of choline sulfate by plants. Meldinger fra Norges Landbrukshogskole 20, 1-53.

Preece, T. F. \& Wong, W. C. (1982). Quantitative and scanning electron microscope observations on the attachment of Pseudomonas tolaasii and other bacteria to the surface of Agaricus bisporus. Physiological Plant Pathology 21, 251-257.

RAINEY, P. B. (1989a). A new laboratory medium for the cultivation of Agaricus bisporus. New Zealand Natural Sciences 16, 109-112.

RAINEY, P. B. $(1989 b)$. The involvement of Pseudomonas putida in the process of basidiome initiation of the cultivated mushroom, Agaricus bisporus. PhD thesis, University of Canterbury, New Zealand.

RaINEY, P. B. (1991). Effect of Pseudomonas putida on hyphal growth of Agaricus bisporus. Mycological Research 95, 699-704.

Rainey, P. B., Cole, A. L. J., Fermor, T. R. \& WoOd, D. A. (1990). A model system for examining the involvement of bacteria in basidiome initation of Agaricus bisporus. Mycological Research 94, 191-195.

ROSENBERG, M. (1981). Bacterial adherence to polystyrene: a replica method of screening for bacterial hydrophobicity. Applied and Environmental Microbiology 42, 375-377.

RosenberG, M. \& KJelleberg, S. (1986). Hydrophobic interactions: role in bacterial adhesion. In Advances in Microbial Ecology, vol. 9, pp. 353-393. Edited by K. C. Marshall. New York: Plenum Press.

RUTTER, P. R. \& VINCENT, B. (1980). The adhesion of micro-organisms to surfaces: physico-chemical aspects. In Microbial Adhesion to Surfaces, pp. 79-92. Edited by R. C. W. Berkeley, J. M. Lynch, J. Melling, P. R. Rutter \& B. Vincent. Chichester: Ellis Horwood.

Schroth, M. N. \& HaNCock, J. G. (1982). Disease-suppressive soil and root-colonizing bacteria. Science 216, 1376-1381. 
StaneK, M. (1976). Bacteria associated with mushroom mycelium (Agaricus bisporus (Lang) Sing.) in hyphosphere. Mushroom Science 9, 197-207.

Stanley, P. M. (1983). Factors affecting the irreversible attachment of Pseudomonas aeruginosa to stainless steel. Canadian Journal of Microbiology 29, 1493-1499.

THIÉRY, J. P. (1967). Mise en évidence des polysaccharides sur coupes fines en microscopie électronique. Journal de Microscopie 6, 9871018.
TolaAs, A. G. (1915). A bacterial disease of cultivated mushrooms. Phytopathology 5, 51-54.

TU, J. C. (1979). Evidence of differential tolerance among some root rot fungi to rhizobial parasitism in vitro. Physiological Plant Pathology 14, $171-177$

Watson, M. L. (1958). Staining of tissue sections for electron microscopy. II. Application of solutions containing lead and barium. Journal of Biophysical and Biochemical Cytology 4, 727-730. 